\title{
Mitosis Inhibitor T 1101 Tosylate
}

National Cancer Institute

\section{Source}

National Cancer Institute. Mitosis Inhibitor T 1101 Tosylate. NCI Thesaurus. Code C151933.

The tosylate salt form of T-1101, an inhibitor of mitosis, with potential antineoplastic activity. Upon oral administration, T-1101 inhibits mitosis, through an as of yet not elucidated mechanism of action, which leads to decreased tumor cell proliferation. 